\title{
Formation and characteristics of zirconium ultrafiltration dynamic membranes of various pore sizes
}

\author{
C.C. Chen, B.H. Chiang* \\ Graduate Institute of Food Science and Technology, National Taiwan University, 59, Lane 144, Keelung Road, Section 4, Taipei, Taiwan, ROC
}

Received 4 August 1997; received in revised form 27 October 1997; accepted 13 December 1997

\begin{abstract}
A dynamic membrane was formed by deposition of colloid particles on a ceramic support. The $\mathrm{ZrOCl}_{2}$ and $\mathrm{H}_{2} \mathrm{SO}_{4}$ mixing method was found to be the best method for obtaining regular size particles. The size of the colloid particles increased linearly with the increases of the $\left[\mathrm{H}_{2} \mathrm{SO}_{4}\right] /\left[\mathrm{ZrOCl}_{2}\right]$ ratio, and ranged from 20 to $200 \mathrm{~nm}$. The dynamic membrane was prepared under a pressure of $0.8 \mathrm{MPa}$ and the particles remained intact and were homogeneously deposited on the ceramic support surface. It is possible to prepare dynamic membranes of molecular weight cut-off greater than 100,000 dalton, and the cut-off increases linearly with the colloid particle size. The dynamic membrane separated BSA from glucose solution effectively. (C) 1998 Elsevier Science B.V.
\end{abstract}

Keywords: Dynamic membranes; Ultrafiltration; Particle size; Pore size; Zirconium

\section{Introduction}

Crossflow ultrafiltration has been in common use for processing of fluid foods for many years. The filtration is carried out by a membrane made of various structural materials, including polymers, sintered metals, and ceramics. These membrane systems offer good filtration but suffer from a number of disadvantages, such as difficulty in cleaning, high costs of installation, and high initial and replacement capital costs.

Membranes suitable for ultrafiltration can be formed by depositing upon a porous support a colloidal substance from a dilute suspension. The suspension is pumped over the support under pressure so that

\footnotetext{
*Corresponding author. Fax: 886-2-2362-0849; e-mail: bhchiang@ccms.ntu.edu.tw
}

the colloid is deposited from the solution passing through the support. These membranes are called dynamic membranes [1]. Past studies of dynamic membranes have focused on the performance of membranes for salt rejection. The best results were obtained with hydrous metal oxides, especially $\mathrm{Zr}(\mathrm{IV})$ oxide [2,3], and the dual layer membranes consisting of a layer of $\mathrm{Zr}(\mathrm{IV})$ oxide followed by a layer of polyacrylic acid [4-8]. Only a few studies on the formation of a dynamic membrane on a crossflow porous tube for the purpose of ultrafiltration [9-11], and the method to form different molecular weight cut-off dynamic ultrafiltration membranes could not be found in the literature. However, it was noticed that the molecular weight cut-off of dynamic membranes might be controlled by the colloid particle size. Therefore, the objectives of this study were to investigate the 
relationship between the colloid particle size and the pore size of dynamic membranes, to establish the procedures which could be used for preparing different molecular weight cut-off ultrafiltration dynamic membranes, and to study the characteristics of the prepared dynamic membranes, so that its potential applications in food processing can be further explored.

\section{Experimental}

\subsection{Apparatus}

The experimental apparatus used is schematically shown in Fig. 1. The dynamic membranes were deposited on a ceramic tube $(0.2 \mu \mathrm{m}$ pore size, module 1T1-70, SCT, France). The ceramic tube having an o.d. of $1.0 \mathrm{~cm}$, an i.d. of $0.7 \mathrm{~cm}$, a length of $25.0 \mathrm{~cm}$ and a wall thickness of $0.15 \mathrm{~cm}$ was inserted into a stainless steel housing. The effective membrane area of the ceramic tube was $50 \mathrm{~cm}^{2}$.

\subsection{Materials}

Inorganic colloids of zirconium compounds were used as the materials for forming the dynamic membranes. Chemical reagent zirconium oxychloride $\left(\mathrm{ZrOCl}_{2} \cdot 8 \mathrm{H}_{2} \mathrm{O}\right)$ manufactured by Nacalai Tesque, Inc. (Kyoto, Japan) was used. The colloid suspension was formed by adding $10^{-3} \mathrm{M} \mathrm{ZrOCl}_{2}$ to various sulfate solutions $\left(\mathrm{H}_{2} \mathrm{SO}_{4}, \mathrm{Na}_{2} \mathrm{SO}_{4},\left(\mathrm{NH}_{4}\right)_{2} \mathrm{SO}_{4}\right.$ and

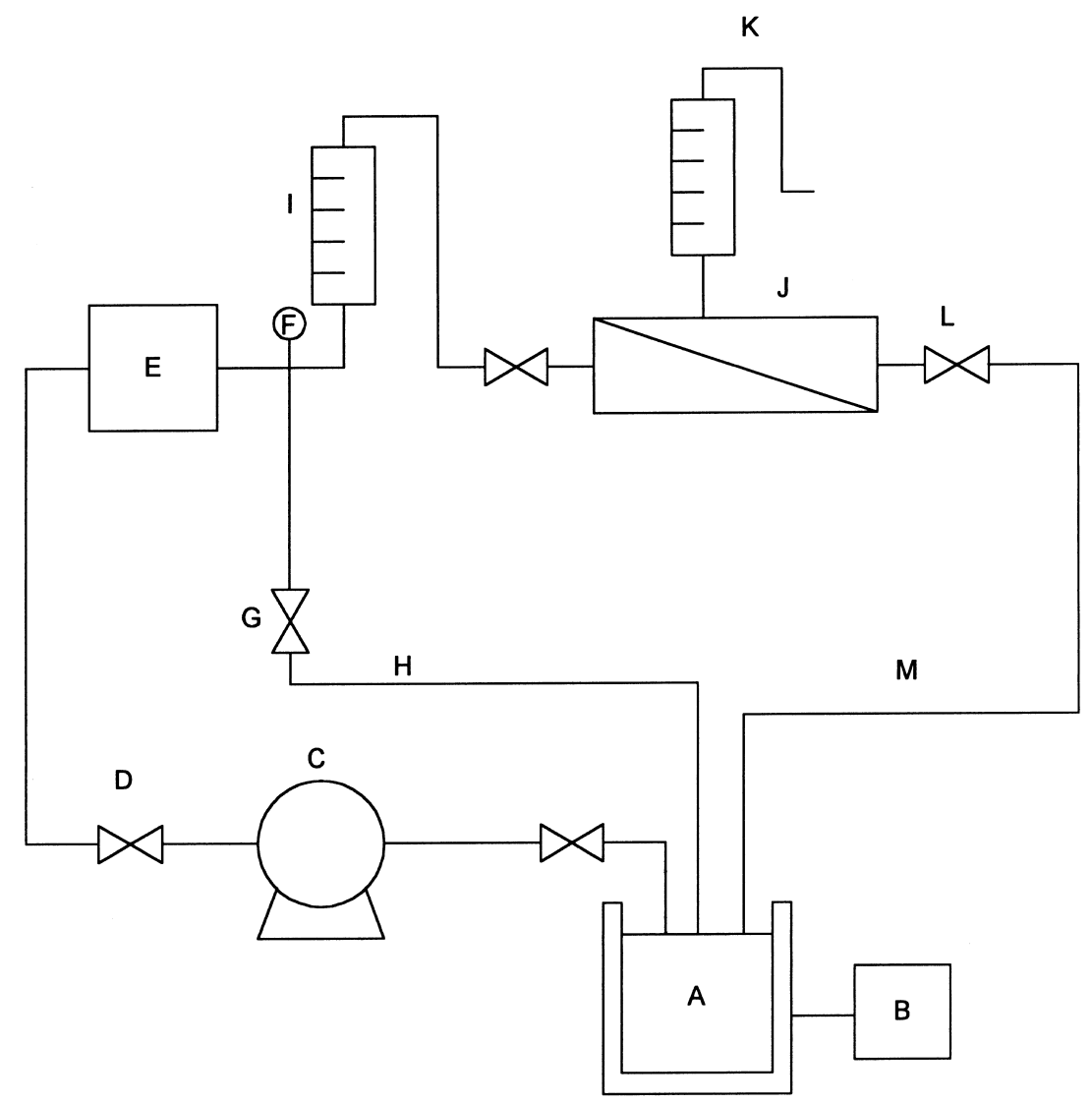

Fig. 1. Schematic diagram of the experimental apparatus used for forming dynamic membrane. (A) Feed tank, (B) temperature controller, (C) pump, (D) manual valve, (E) pressure-stabilized unit, (F) pressure gauge, (G) manual bypass valve, (H) bypass loop, (I) flow meter, (J) membrane module, $(\mathrm{K})$ permeate, $(\mathrm{L})$ manual control valve, $(\mathrm{M})$ retentate. 
$\mathrm{K}_{2} \mathrm{SO}_{4}$ ) with concentrations ranging from 0.6 to $1.5 \times 10^{-3} \mathrm{M}$ at room temperature, and then aged for overnight [12].

\subsection{Procedures}

Dynamic membranes were formed on the ceramic support by circulating colloid solution through the experimental apparatus for $1 \mathrm{~h}$ at $0.8 \mathrm{MPa}$ pressure, flow rate $10 \mathrm{l} / \mathrm{min}$, and $25^{\circ} \mathrm{C}$. The dynamic membranes obtained were stored in a closed container of $100 \%$ relative humidity before analyzing for its characteristics and process performance.

\subsection{Analyses}

To measure the molecular weight cut-off of the dynamic membranes formed, solutions containing $0.012 \%$ of dextran of various molecular weights (Sigma, St. Louis, MO, USA) were ultrafiltered under the standard conditions of pressure $0.2 \mathrm{MPa}$, flow rate $5 \mathrm{l} / \mathrm{min}$, and $25^{\circ} \mathrm{C}$. The dextran concentration was measured by phenol-sulfuric acid method [13]. A piece of dynamic membrane was oven dried at $50^{\circ} \mathrm{C}$, and pore size and structure analyzed by a mercury pore size analyzer (Micromeritics, Autopore II 9220, Norcross, GA, USA). The rejection $(R)$ of the membranes were determined by: $R=1-C_{\mathrm{p}} / C_{\mathrm{b}}$, where $C_{\mathrm{p}}$ was the concentration of the dextran in the permeate, and $C_{\mathrm{b}}$ the concentration of dextran in the bulk solution.

The average particle sizes of the colloids were determined by transmission electron microscope (TEM, Hitachi H-7100, Japan). To observe the surface structure, a fraction of the ceramic tube deposited with dynamic membrane was freeze dried and shadowed with gold under vacuum, and then examined by scanning electron microscope (SEM, Hitachi S-2400).

After the colloid suspension was centrifuged, the precipitate was washed with distilled water. This procedure was repeated three times. The structures of the colloid particles were analyzed by X-ray scattering (Philips PW1729, Philips, The Netherlands) at $30 \mathrm{kV}$ voltage and $20 \mathrm{~mA}$ current.

\subsection{Model food solution filtration test}

A solution containing glucose (mw 180) $120 \mathrm{ppm}$ and bovine serum albumin (BSA, mw 80,000)
$200 \mathrm{ppm}$ was filtered through the dynamic membrane at pressure $0.2 \mathrm{MPa}$, flow rate $2.7 \mathrm{l} / \mathrm{min}$ and room temperature. While the retentate was circulated back to the feed tank, the permeate was collected and analyzed. The glucose concentration was determined by phenol-sulfuric acid method [13] and the BSA was by Lowry method [14].

\section{Results and discussion}

\subsection{Preparation of colloid particles of different sizes}

Among the sulfates tested for forming $\mathrm{Zr}(\mathrm{IV})$ colloid, the $\mathrm{H}_{2} \mathrm{SO}_{4}$ was the most effective one for controlling the particle size. It appeared that the cation might interfere with the polymerization. The presence of the cation in the solution would encourage the development of new polymerizing cores rather than growing on the old polymers. The particle size increased with increasing the $\left[\mathrm{SO}_{4}^{-2}\right] /\left[\mathrm{Zr}^{+4}\right]$ ratio (Fig. 2). Their relationship could be expressed by the following equation with a regression coefficient $\left(r^{2}\right)$ of 0.99 :

$Y=5.69 X+53.84 X^{2}-6.26 X^{3}$

where $Y$ is the particle diameter in $\mathrm{nm}$, and $X$ is the $\left[\mathrm{SO}_{4}^{-2}\right] /\left[\mathrm{Zr}^{+4}\right]$ ratio. The TEM photos of the particle also showed that the higher the $\left[\mathrm{H}_{2} \mathrm{SO}_{4}\right] /\left[\mathrm{ZrOCl}_{2}\right]$ concentration ratios, the larger are the particles formed, and the particles were spherical and uniform (Fig. 3). The particles of size ranging from 10 to $200 \mathrm{~nm}$ could be prepared by changing the $\left[\mathrm{H}_{2} \mathrm{SO}_{4}\right] /\left[\mathrm{ZrOCl}_{2}\right]$ ratio.

The $\mathrm{pH}$ of the colloid suspension prepared at various $\left[\mathrm{H}_{2} \mathrm{SO}_{4}\right] /\left[\mathrm{ZrOCl}_{2}\right]$ ratios ranged from 2.48 (ratio $=1.5: 1)$ to 2.68 (ratio $=0.7: 1$ ). It appeared that the $\mathrm{pH}$ might not be a major factor affecting the particle size in this study. The X-ray diffraction pattern of the particles shows two to three broad diffraction peaks, indicating that the colloid particle is a microcrystalline materials.

\subsection{Preparation of dynamic membranes}

When the colloid suspension was circulated through the ceramic membrane system, the colloid particles deposited on the inner surface of the ceramic tube, and 


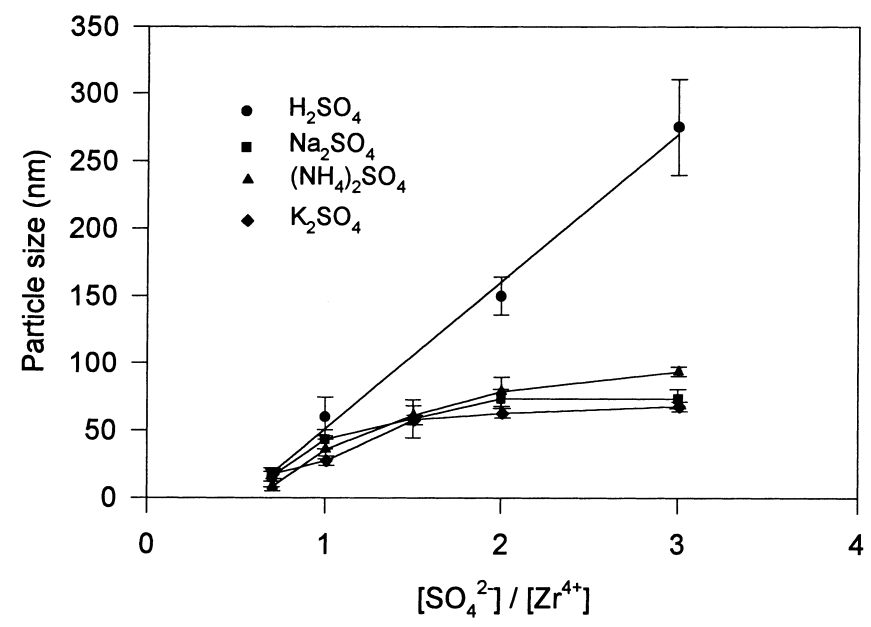

Fig. 2. The relationship between colloid particle size (nm) and $\left[\mathrm{SO}_{4}^{2-}\right] /\left[\mathrm{Zr}^{4+}\right]$ ratio.

the permeate flux decreased with time as shown in Fig. 4. The colloid particles accumulated on the ceramic surface, compacted by pressure, thus, the dynamic membrane was formed. The longer the circulation time the lower the permeate flux obtained. However, the flux reached a steady state after $\approx 1 \mathrm{~h}$ of circulation, indicating that a stable layer of dynamic membrane was formed. Furthermore, the smaller the colloid particle size, the lower the flux was observed during the circulation of the colloid suspension, suggesting that a more compact dynamic membrane with higher hydraulic resistance was formed by smaller particles.

\subsection{Characteristics of the dynamic membrane}

The retention property of the dynamic membrane was dependent on the size of the colloid particles forming the membrane, which, in turn, was controlled by the $\left[\mathrm{H}_{2} \mathrm{SO}_{4}\right] /\left[\mathrm{ZrOCl}_{2}\right]$ ratio during colloid particle formation. Table 1 shows the rejections of the dynamic membranes prepared with the colloid particles which were formed at various $\left[\mathrm{H}_{2} \mathrm{SO}_{4}\right] /$ $\left[\mathrm{ZrOCl}_{2}\right]$ ratios. The membrane formed at the $\left[\mathrm{H}_{2} \mathrm{SO}_{4}\right] /\left[\mathrm{ZrOCl}_{2}\right]$ ratio of 1.0 retained more than $90 \%$ of the dextran molecules of molecular weight $2.2 \times 10^{7}$ dalton. However, the membrane formed at $\left[\mathrm{H}_{2} \mathrm{SO}_{4}\right] /\left[\mathrm{ZrOCl}_{2}\right]$ ratio of 0.6 could retain more than $90 \%$ of the $1.5 \times 10^{5}$ dalton dextran. If one uses $90 \%$ rejection as a criterion for determining the nominal molecular weight cut-off of the dynamic membrane, it can be concluded that the dynamic membranes with molecular weight cut-offs ranging from $10^{5}$ and above could be prepared by adjusting the $\left[\mathrm{H}_{2} \mathrm{SO}_{4}\right] /\left[\mathrm{ZrOCl}_{2}\right]$ ratio using the following equation:

\section{Table 1}

The rejection $(\%)$ of different molecular weight dextrans by the dynamic membranes which were prepared with colloid particles of different sizes controlled by $\left[\mathrm{H}_{2} \mathrm{SO}_{4}\right] /\left[\mathrm{ZrOCl}_{2}\right]$ ratios

\begin{tabular}{llllll}
\hline$\left[\mathrm{H}_{2} \mathrm{SO}_{4}\right] /\left[\mathrm{ZrOCl}_{4}\right]$ ratio & \multicolumn{2}{l}{ Dextran molecular weight (dalton) } \\
\cline { 2 - 6 } & $1.1 \times 10^{4}$ & $1.5 \times 10^{5}$ & $5.0 \times 10^{5}$ & $2.0 \times 10^{6}$ & ND \\
\hline 0.6 & 66.1 & 94.2 & $\mathrm{ND}$ & $\mathrm{ND}$ & $\mathrm{ND}$ \\
0.7 & 19.0 & 87.6 & 94.4 & 99.9 & ND \\
0.8 & 16.0 & $\mathrm{ND}$ & 90.5 & 92.0 & ND \\
0.9 & 2.4 & $\mathrm{ND}$ & 61.6 & 81.8 & ND \\
1.0 & $\mathrm{ND}$ & $\mathrm{ND}$ & 42.9 & 95.6 \\
\hline
\end{tabular}

ND: not determined. 
(a)

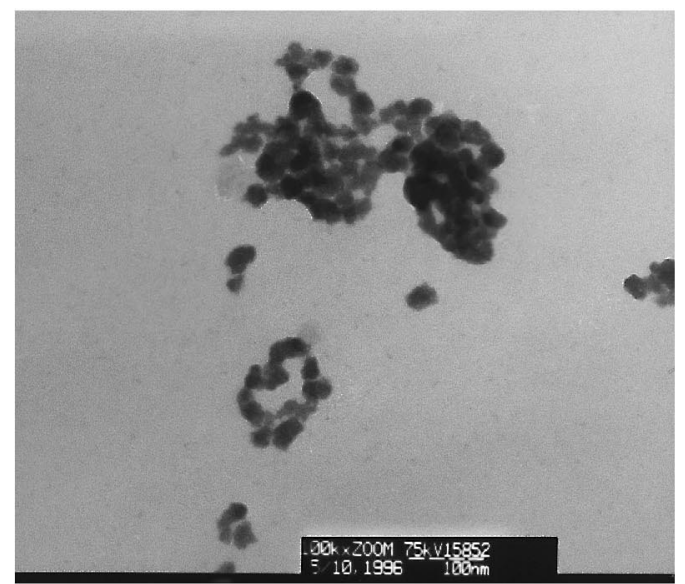

(b)

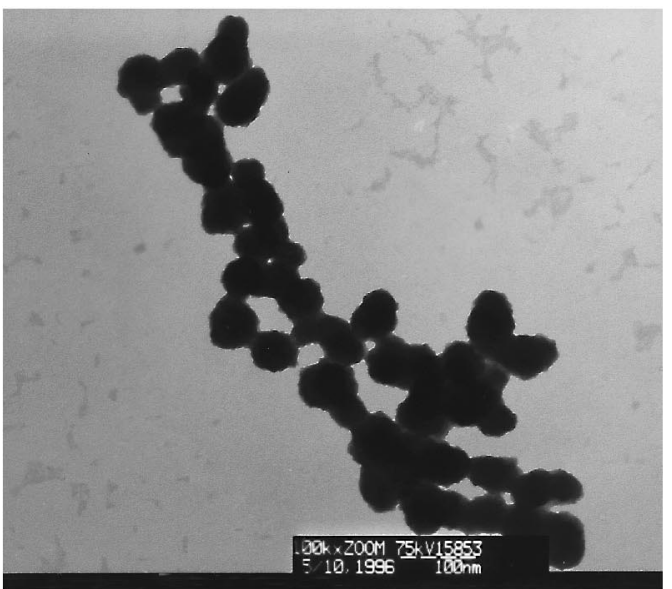

(e)

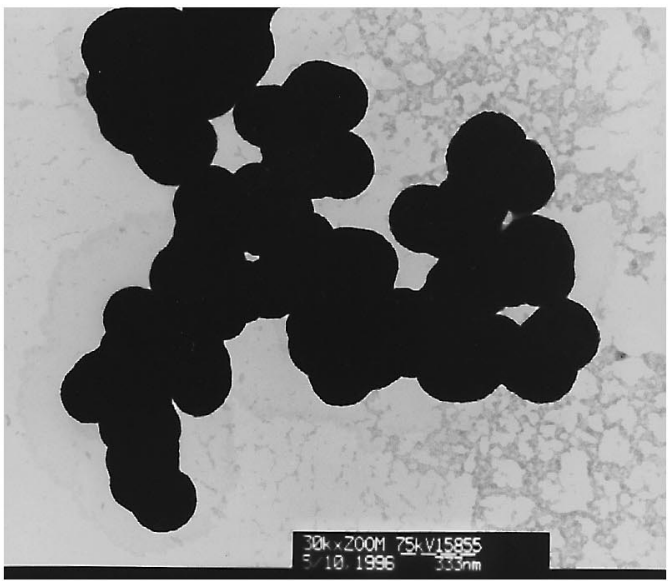

(d)

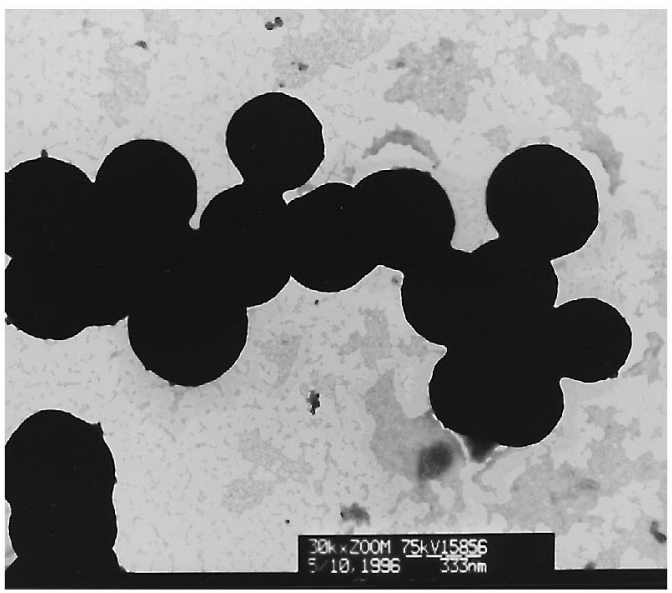

(c)

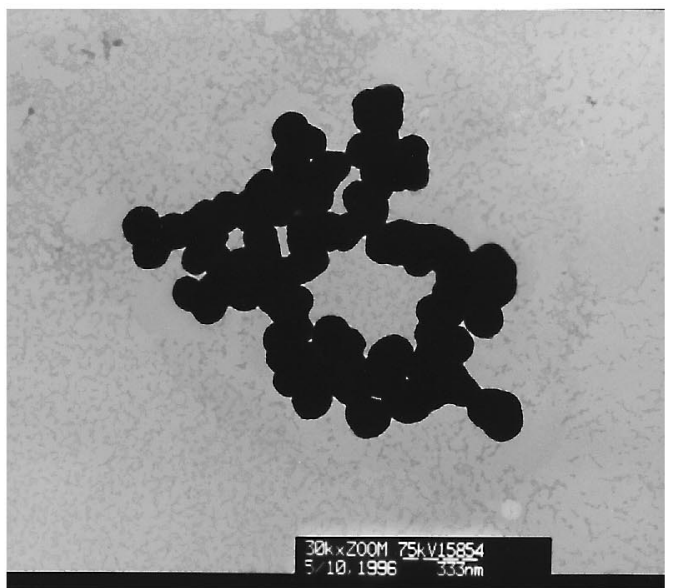

Fig. 3. TEM photographs of the colloid particles formed at different $\left[\mathrm{H}_{2} \mathrm{SO}_{4}\right] /\left[\mathrm{ZrOCl}_{2}\right]$ ratios. a, b $(\times 100 \mathrm{k}), \mathrm{c}, \mathrm{d}$ and e $(\times 30 \mathrm{k})$ were $0.7,1$, 2,3 and $4\left[\mathrm{H}_{2} \mathrm{SO}_{4}\right] /\left[\mathrm{ZrOCl}_{2}\right]$ ratios, respectively. 


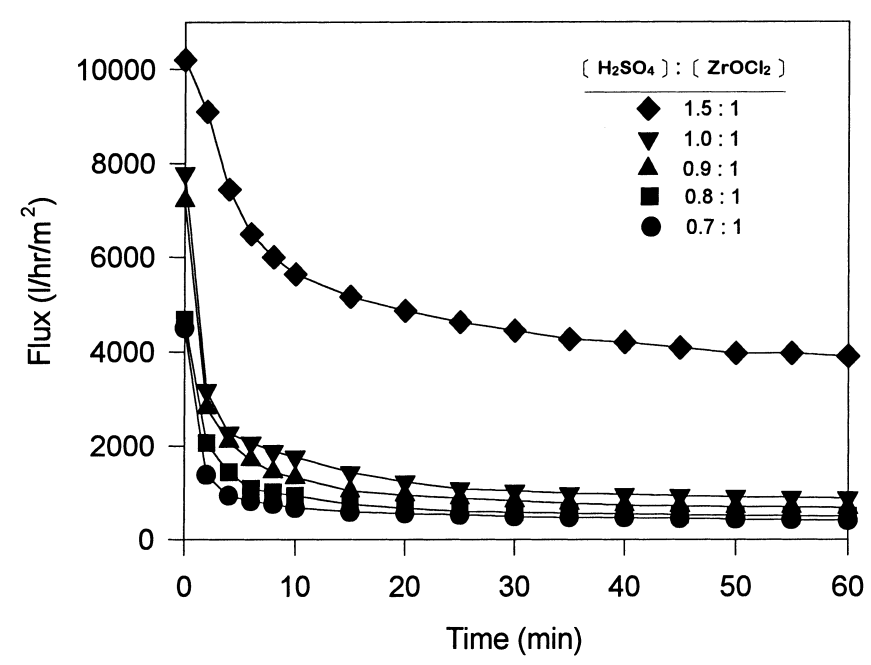

Fig. 4. Flux decline with time during formation of dynamic membranes using various $\left[\mathrm{H}_{2} \mathrm{SO}_{4}\right] /\left[\mathrm{ZrOCl}_{2}\right]$ ratios.

$\log Z=3.71+0.054 Y$

where $Z$ is the molecular weight cut-off in dalton, and $Y$ is the particle size of Eq. (1).The regression coefficient $\left(r^{2}\right)$ for Eq. (2) is 0.99 .

\subsection{The structural properties of dynamic membranes}

Fig. 5 shows the SEM photographs of the dynamic membrane deposited on the ceramic support. The colloid particles, in general, remained intact, and were still spherical in shape. However, a close observation of the SEM photograph (Fig. 5(a)) could find some flattened particle contacts on the surface of the membrane, suggesting that the colloid particles were probably partially compressed to form the dynamic membrane.

The average diameters of the colloid particles formed at various $\left[\mathrm{H}_{2} \mathrm{SO}_{4}\right] /\left[\mathrm{ZrOCl}_{2}\right]$ ratios and the pore diameters of the dynamic membranes formed by these particles are given in Table 2. Again, larger the particle size, bigger is the pore diameter. Considering two possible types of particle packing (Fig. 6), and the cross section areas of the pores of each type of packing were calculated. Based on the pore areas, one could estimate the diameters of the pores by assuming that they were round in shape. The estimated pore diameters of type A and B packings are also given in Table 2. It appeared that the estimated pore diameters of type A packing fitted the actual pore sizes of the membranes formed by smaller particles, while the type B packing matched the larger particle ones. This observation suggested that the smaller colloid particles not only formed smaller pores, but also had more compact stacking than that of the larger particles. However, the deformation of colloid particles as shown by the SEM photograph would complicate the packing phenomena.

Table 2

Structural properties of the dynamic membranes

\begin{tabular}{llllll}
\hline $\begin{array}{l}{\left[\mathrm{H}_{2} \mathrm{SO}_{4}\right] /\left[\mathrm{ZrOCl}_{2}\right]} \\
\text { ratio }\end{array}$ & $\begin{array}{l}\text { Particle } \\
\text { diameter }(\mathrm{nm})\end{array}$ & $\begin{array}{l}\text { Actual pore } \\
\text { diameter }(\mathrm{nm})\end{array}$ & $\begin{array}{l}\text { Estimated pore diameter } \\
\text { based on type A packing }\end{array}$ & $\begin{array}{l}\text { Estimated pore diameter } \\
\text { based on type B packing }\end{array}$ & $\begin{array}{l}\text { Porosity } \\
(\%)\end{array}$ \\
\hline 0.7 & 28 & 6 & 6 & 15 & 11 \\
0.9 & 44 & 15 & 10 & 23 & 29 \\
1.0 & 53 & 23 & 12 & 28 & 38 \\
1.5 & 108 & 61 & 25 & 57 & 56 \\
\hline
\end{tabular}

\footnotetext{
${ }^{\mathrm{a}}$ Porosity $=$ total pore volume/total volume of dynamic membrane.
} 
(a)
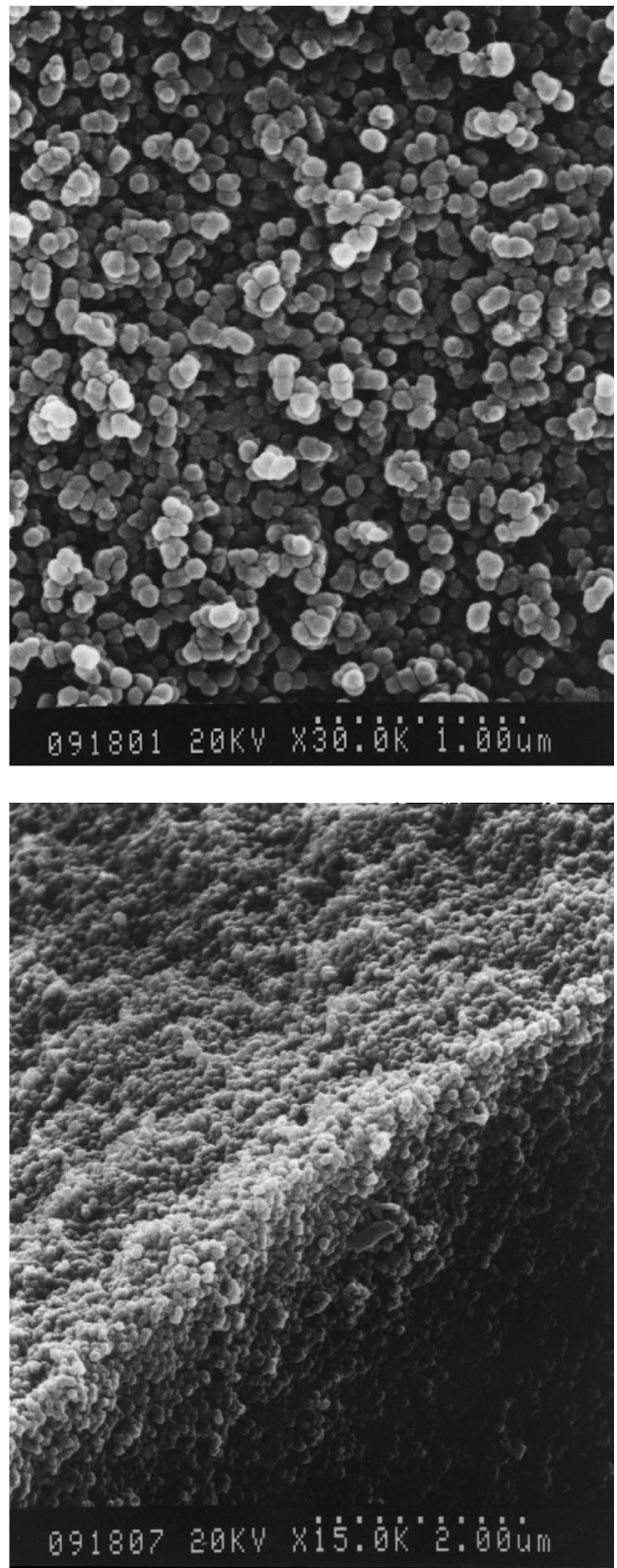

(b)

Fig. 5. SEM photographs of the dynamic membranes on the surface of ceramic tube. (a) Top view $(\times 30 \mathrm{k})$; (b) side view $(\times$ $15 \mathrm{k})$. The colloid particles were formed using $\left[\mathrm{H}_{2} \mathrm{SO}_{4}\right] /\left[\mathrm{ZrOCl}_{2}\right]$ ratio of $1: 1$.

The porosities of the dynamic membranes were estimated by the ratio of total pore volume to the total volume of the dynamic membrane analyzed by the mercury pore analyzer (Table 2). For packing of monosize spheres, the face-centered cubic is the most
Table 3

Food model solution containing glucose and bovine serum albumin (BSA) was filtered by the dynamic membrane which was formed by using colloidal solution of $\left[\mathrm{H}_{2} \mathrm{SO}_{4}\right] /\left[\mathrm{ZrOCl}_{2}\right]$ ratio of 0.6 under $0.2 \mathrm{MPa}$ pressure

\begin{tabular}{llll}
\hline Filtration time (min) & \multicolumn{2}{l}{ Rejection $(\%)$} & Flux $\left(1 / \mathrm{h} / \mathrm{m}^{2}\right)$ \\
\cline { 2 - 3 } & $\begin{array}{l}\text { Glucose } \\
(\mathrm{mw} 180)\end{array}$ & $\begin{array}{l}\text { BSA } \\
(\mathrm{mw} 80,000)\end{array}$ \\
\hline 1 & 5.8 & 98.3 & 68.4 \\
30 & 3.7 & 98.4 & 55.2 \\
60 & 1.8 & 98.3 & 42.0 \\
90 & 1.6 & 96.4 & 36.0 \\
120 & 1.9 & 97.8 & 33.0 \\
\hline
\end{tabular}

compact one and has a porosity of $25.9 \%$ [15]. The experimental results, however, showed that the dynamic membrane of pore diameter of $6 \mathrm{~nm}$ had a $11 \%$ porosity. This unexpected low value may be attributed to the particles deformation during membrane formation.

The pore size distribution of the dynamic membranes is shown in Fig. 7. Smaller the particle size, the narrower is the pore size distribution. Nevertheless, the prepared dynamic membranes, in general, had a rather sharp pore size distribution, which, in turn, could ensure a satisfactory separation during application.

\subsection{The food model solution filtration test}

A solution containing glucose and BSA was filtered by the dynamic membranes which was formed using the $\left[\mathrm{H}_{2} \mathrm{SO}_{4}\right] /\left[\mathrm{ZrOCl}_{2}\right]$ ratio of 0.6. The BSA was almost $100 \%$ rejected; while, the glucose transmitted through the membrane nearly freely (Table 3 ). However, the flux declined from the initial value of $68 \mathrm{l} / \mathrm{h} /$ $\mathrm{m}^{2}$ to $30 \mathrm{l} / \mathrm{h} / \mathrm{m}^{2}$ during $2 \mathrm{~h}$ of operation. It appeared that the prepared dynamic membrane could provide a satisfactory separation, but the problem of membrane fouling should not be overlooked.

\section{Conclusion}

The regular size colloid particles ranging from 20 to $200 \mathrm{~nm}$ could be prepared by mixing $\mathrm{H}_{2} \mathrm{SO}_{4}$ and $\mathrm{ZrOCl}_{2}$ at various ratios. Deposition of the colloid particles on a porous ceramic support could form 


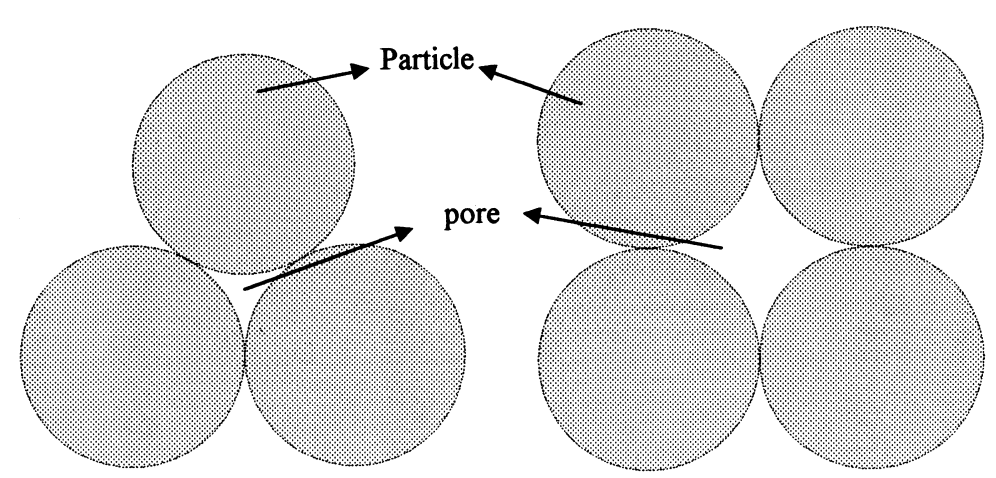

Type A

Type B

Fig. 6. Various types of colloid particle packing.

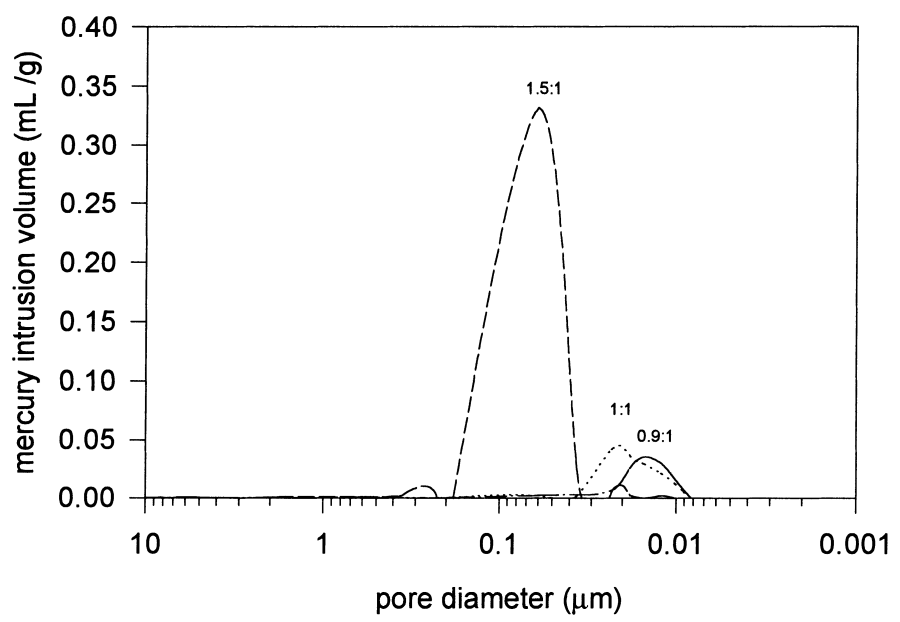

Fig. 7. The pore size distribution of the dynamic membranes prepared by using various $\left[\mathrm{H}_{2} \mathrm{SO}_{4}\right] /\left[\mathrm{ZrOCl}_{2}\right]$ ratios analyzed by the mercury pore size analyzer.

dynamic membranes of molecular weight cut-off greater than 100,000 dalton. Although the prepared dynamic membrane separated BSA from glucose in a solution effectively, a dramatic flux decline due to fouling was also observed. Further research is needed to reduce the fouling phenomena, possibly by reducing the membrane thickness or preparing an asymmetric dynamic membrane.

\section{Acknowledgements}

This research was supported by the National Science Council of ROC under the project no. NSC-85-2214-E-003-033.

\section{References}

[1] A.E. Marcinkowsky, K.A. Kraus, H.O. Phillips, J.S. Johnson Jr., A.J. Shor, Hyperfiltration studies. IV. Salt rejection by dynamically formed hydrous oxide membranes, J. Am. Chem. Soc. 88 (1966) 5744.

[2] D. Freilich, G.B. Tanny, The formation mechanism of dynamic hydrous $\mathrm{Zr}(\mathrm{IV})$ oxide membranes on microporous supports, J. Colloid Interface Sci. 64 (1978) 362.

[3] A.J. Shor, K.A. Kraus, W.T. Smith Jr., J.S. Johnson Jr., Hyperfiltration studies. XI. Salt-rejection properties of dynamically formed hydrouszirconium(IV) oxide membranes, J. Phys. Chem. 72 (1968) 2200.

[4] D. Freilich, G.B. Tanny, Hydrodynamic and microporous support pore size effects on the properties and structure of dynamically formed hydrous $\mathrm{Zr}(\mathrm{IV})$-polyacrylate membranes, Desalination 27 (1978) 233. 
[5] J.S. Johnson Jr., R.E. Minturn, P.H. Wadia, Hyperfiltration. XXI. Dynamically formed hydrous $\mathrm{Zr}(\mathrm{IV})$ oxide-polyacrylate membranes, J. Electroanal. Chem. 37 (1972) 267.

[6] F.G. Neytzell-de Wilde, C.A. Buckley, M.P.R. Cawdron, Dynamically formed hydrous zirconium (IV) oxide/polyacrylic membranes; low pressure formation, high pressure evaluation, Desalination 70 (1988) 121.

[7] T. Nomura, S. Kimura, Properties of dynamically formed membranes, Desalination 32 (1980) 57.

[8] G.B. Tanny, J.S. Johnson Jr., The structure of hydrous Zr(IV) oxide-polyacrylate membranes: Poly(acrylic acid) deposition, J. Appl. Polym. Sci. 22 (1978) 289.

[9] S. Nakao, T. Nomura, S. Kimura, A. Watanabe, Formation and characteristics of inorganic dynamic membranes for ultrafiltration, J. Chem. Eng. Jpn. 19 (1986) 221.

[10] T. Ohtani, A. Watanabe, C. Hoshino, S. Kimura, Application of dynamic membrane to ultrafiltration, Kagaku Kogaku Ronbunshu 11 (1985) 140.
[11] T. Ohtani, M. Nakjima, Y. Nawa, A. Watanabe, Formation of dynamic UF membrane with fine Zr particles, J. Membr. Sci. 64 (1991) 273.

[12] T. Ohtani, Y. Nawa, A. Watanabe, M. Nakajima, H. Nabeya, Manufacture of zirconium micro-particles and their use in dynamic membranes, Jpn. Kokai Tokkyo Koho. JP 02141424 (1990) 133

[13] M. Dubois, K.A. Gilles, J.K. Hamilton, P.A. Rebers, F. Smith, Colorimetric method for determination of sugars and related substances, Anal. Chem. 28 (1956) 350.

[14] O.H. Lowry, N.J. Rosebrough, A.L. Farr, R.J. Randall, Protein measurement with the folin phenol reagent, J. Biol. Chem. 193 (1951) 265.

[15] R.M. Germar, Packing of monosize spheres, Particle packing characteristics, Metal powder industries federation, Princeton, New Jersey, 1989, pp. 89-111. 